\title{
Influence of Extra Weight and Tire Pressure on Fuel Consumption at Normal Tractor Slippage
}

\author{
Vidas Damanauskas ${ }^{1}$, Algirdas Janulevičius ${ }^{1}$ \& Gediminas Pupinis ${ }^{1}$ \\ ${ }^{1}$ Institute of Power and Transport Machinery Engineering, Aleksandras Stulginskis University, Lithuania \\ Correspondence: Algirdas Janulevičius, Aleksandras Stulginskis University, Studentų Str. 15, 53361 \\ Kaunas-Akademija, Lithuania. Tel: 370-37-752-285. E-mail: algirdas.janulevicius@asu.lt
}

Received: November 2, 2014

doi:10.5539/jas.v7n2p55
Accepted: November 25, 2014 Online Published: January 15, 2015

URL: http://dx.doi.org/10.5539/jas.v7n2p55

\begin{abstract}
Tire pressure and wheel load are both easily managed parameters which play a significant role in tillage operations for limiting slip which involves energy loss. To a great extent, this aspect affects the fuel consumption and the time required for soil tillage. The study was focused on the tire pressure and extra weight variation effect on fuel consumption and work productivity for soil tillage at normal tractor wheels slippage $(7-15 \%)$. The experimental research unit composed of an $82.3 \mathrm{~kW} 4 \mathrm{WD}$ tractor and a reversible 4-bodies plough is presented. Tests were carried out on a stubble loam, where slip of tractor driving wheels was $<15 \%$, tractor front ballast mass was varied in the range from 0 to $520 \mathrm{~kg}$ and inflation pressure in the tires from $240 \mathrm{kPa}$ to $100 \mathrm{kPa}$. Dependences of tractor performance indicators on ballast mass and tires inflation pressure are presented. When tractor tire slip varies in the range from 7 to 15 percent (which is normal slip in the soil), reducing the tires inflation pressure decreases the driving wheel slip and fuel consumption, while increases work productivity. Increasing the additional mass of the tractor (adding ballast weights) decreases the driving wheel slip, increases work productivity, but also increases fuel consumption and soil compaction.
\end{abstract}

Keywords: tractor, slippage, fuel consumption, extra weight, tire pressure, tillage operation

\section{Introduction}

Energy systems, transport and agriculture are named as the main sectors that need more attention for the appropriate measures in order to reduce fuel consumption and unfriendly impact on the environment (Dagiliūte \& Juknys, 2012; Szendrö \& Török, 2014). Agricultural mechanization is required to sustain food production with high productivity, but fuel resource limitation has spurred both tractor manufacturers and users to address their fuel consumptions. Fuel consumption and exhaust emissions, including harmful components, can be reduced only by complex optimization of technological processes and tractor operating modes (Backman, Oksanen, \& Visala, 2013; Janulevičius, Juostas, \& Pupinis, 2013; Magalhães, Souza, Santana, \& Sabbag, 2013; Moitzi, Haas, Wagentristl, Boxberger, \& Gronauer, 2013; Khambalkar, Pohare, Katkhede, Bunde, \& Dahatonde, 2010; Kheiralla, Azmi, Zohadie, \& Ishak, 2004).

Agricultural tractors combined with diverse implements are the basic tools used in field production to conduct different field operations. Agricultural tractors commonly employ a four-wheel drive (4WD) transmission. Four-wheel drive tractors offer a number of advantages over two-wheel drive; the main advantage of the front-wheel assist is that it improves the tractor's ability to cross soft, wet, slippery and/or uneven terrain (Molari, Bellentani, Guarnieri, Walker, \& Sedoni, 2012; Patterson, Gray, Bortolin, \& Vantsevich, 2013). However, Wong (2010) and Vantsevich (2008) noted that under certain circumstances, a tendency exists for four-wheel drive tractors to suffer a reduction in power delivery efficiency and an increase in fuel consumption as a result of interaction between front and rear wheels being less than optimal.

Pulling ability of any tractor depends on many factors, includings engine power, tractor mass, contact area between tires and the ground and soil strength (Lyasko, 2010; Moitzi et al., 2013; Senatore \& Sandu, 2011; Srinivasa Rao, Ramji, \& Naidu, 2012; Stoilov \& Kostadinov, 2009; Wong, 2010). When the soil is strong (dry), the cohesion is good, which results in greater pulling force, less wheel slip and lower rolling resistance (Moitzi et al., 2013). While the soil is at the plastic state (wet), the cohesion is good, but the wheels slip and the rolling resistance is high, which causes greater power losses and reduces tractor pulling efficiency (Battiato \& Diserens, 2013; Wong, 2010). 
Driving-wheel slip and rolling resistance are regarded as the main sources of power loss. The research indicates that 20 to $55 \%$ of available tractor power is lost in the process of interaction between tires and soil surface (Peca et al., 2010; Šmerda \& Čupera, 2010; Taghavifar \& Mardani, 2014). The rolling resistance has on approximately constant relation with low velocities. The rolling resistance of the wheel is increasingly influenced by inflation pressure and vertical load than velocities in agricultural works. Also, Taghavifar and Mardani (2013) noted that increase of inflation pressure suggests reverse relation with rolling resistance particularly at higher values of vertical load. A single-wheel test facility (Taghavifar \& Mardani, 2013) was utilized to investigate the effect of velocity, tire inflation pressure, and vertical load on rolling resistance of wheel. The results showed that rolling resistance is less affected by velocities of tractors in farmlands but is much influenced by inflation pressure and vertical load (Taghavifar \& Mardani, 2013).

Fuel consumption during tractor operation is highly dependent on the engine rotational speed and load characteristics. In most cases, the most productive and cost-effective work is obtained when engine load is less than $80 \%$ of its rated power and the engine rotational speed does not exceed $80 \%$ of its rated rotational speed (Grisso et al., 2011; Janulevičius et al., 2013; Juostas \& Janulevičius, 2014; Lacour, Burgun, Perilhon, Descombes, \& Doyen, 2014; Moitzi et al., 2013). In order to reach maximum economic efficiency of works performed by agricultural equipment, tractors with higher pulling power are unavoidable for usage. Draft depends on the pulling power and running speed. Basically, operational speeds of tractors in the farm cannot exceed to high levels. Operational speed of 3-15 $\mathrm{km} \mathrm{h}^{-1}$ prevails in agricultural work. Deviations from the operational speed deteriorate the quality of work and increase energy consumption. For example, faster tilling greatly increases the dynamic effects on the soil, the earth is thrown strongly and more energy is consumed (Hashemi, Ahmad, Othman, \& Sulaiman, 2012; Khambalkar et al., 2010; Moitzi et al., 2013). For agricultural work to be carried out at the operational speeds, especially on soft soil, the traction power is limited by the grip between driving wheels and the soil. In order to effectively use the engine power and not to deviate from the operational speed, working width has to be increased (Lacour et al., 2014; Moitzi et al., 2013). That is, the tractor has to be loaded with higher traction force. As a rule, when a tractor is loaded with high traction force, the slip of driving wheels exceeds the permissible limits. Terramechanics points out two essential ways to reduce the slip. One possibility is to increase tractor's mass by adding ballast. The other possibility is to enlarge the contact area between tires and terrain. With enlargement of the contact area between tires and terrain, tractor tires make less negative effect on the field and the result is less compacted soil under the tracks (Saengprachatanarug, Ueno, Taira, \& Okayasu, 2013; Srinivasa Rao et al., 2012; Way \& Kishimoto, 2004). Furthermore, due to the larger contact area, rolling resistance is smaller in soft soil (Battiato \& Diserens, 2013; Molari et al., 2012; Taghavifar \& Mardani, 2013).

Rolling resistance of driving wheels and slip of driving wheels are two factors that influence tractor pulling power, and these factors are interrelated. For the tractor driving on a hard-surface road, rolling resistance of the wheels becomes lower when inflation pressure in the tires is increased. On the soil, the lower the inflation pressure in the tires, the more shallow the track and less rolling resistance. For the tractor driving at low speeds (e.g., for soil tillage operations) pulling force is limited by contact area between tires and the soil. Driving wheels are not able to transfer all available engine power due to the fact that the grip between driving wheels and the soil realizes smaller propulsive force (Lyasko, 2010; Xia, 2011). In order to increase the pulling force, it is necessary to improve the conditions for the grip between driving wheels and the soil.

Totally different results are obtained when the tractor is working at higher speeds. For example, when stubble is being tilled at a speed higher than $15 \mathrm{~km} \mathrm{~h}^{-1}$, pulling power is limited by engine power. This means that almost all power of the engine can be converted into pulling power (Wong, 2010; Zoz \& Grisso, 2003). In such conditions, the ballast mass does not give an additional effect (Janulevičius \& Giedra, 2008). Therefore, what positive effect is obtained by using ballast mass depends on the soil characteristics, inflation pressure in the tires, tractor working speed, etc.

Variations in soil structure and surface roughness affect variations in implement resistance and pulling force. In case of tractors with manual transmissions, engine torque reserve helps to overcome the increased resistance to pulling (Battiato \& Diserens, 2013; Grisso et al., 2011). In order to not overload the engine and let it operate normally, work is usually done by not utilizing the full load. When pulling force increases, engine works in a range of higher torque, so greater traction is ensured even without switching into lower gear. Power reserve in the conditions of agricultural production varies in the range from 6 to 18 percent of total engine power. Most of the tractors usually are operated at 60-70 percent of maximum load (Grisso et al., 2011; Janulevičius et al., 2013; Lacour at al., 2014). Test results show that when a tractor is used in a step less variable transmission control mode, the engine can be loaded almost 100\% (Macor \& Rossetti, 2013). 
In tillage work, draft can be increased by up to 15 percent depending on the ballast mass and the place where it is mounted (Janulevičius \& Giedra, 2008; Pranav \& Pandey, 2008). Results of tests carried out by researchers of tractors show that applying ballast mass is not the best solution to reduce tractor slip. This method has a very important drawback - A danger always remains of excessive compacting of the soil and damaging its structure at great depths (much deeper than it is tilled), which can reduce soil productivity (Keller, 2005; Saengprachatanarug et al., 2013; Way \& Kishimoto, 2004). Extra mass makes the tires sink deeper into the soil and leave tracks. Depth of the tracks depends on the mass, soil hardness, tire dimensions and tire inflation pressure. Tire inflation pressure also influences how much the wheels slip and is regarded as on important factor affecting tractor field performance indicators, such as draft power (Senatore \& Sandu, 2011; Srinivasa Rao et al., 2012; Šmerda \& Čupera, 2010; Taghavifar \& Mardani, 2013).

Currently, tractor performance researchers recommend reducing the inflation pressure in the tires, thus increasing contact area between the tire and the ground. It means that tractor mass is distributed over a larger contact area and the wheels' pressure on the soil decreases. Driving wheels sink less into the soil, tracks are not so deep and the rolling resistance is reduced. For example, resistance of 8-12 $\mathrm{cm}$ depth track corresponds to driving up a slope of $10 \%$. Normally, slip of driving wheels should not exceed $15 \%$, otherwise it causes lower productivity, cost-effectiveness, and intensive destruction of the soil (Keller, 2005; Moitzi et al., 2013; Saengprachatanarug et al., 2013; Šmerda \& Čupera, 2010). If slip of driving wheels in the soil is low (less than 6-7\%), it is also unacceptable, as traction power is not utilized and energy consumption per unit of performed work increases. Slip is low when driving wheels are loaded with too big weight force. In this case the power is used to carry the excess mass and press the soil, and fuel consumption may increase by $15 \%$ (Wong, 2010). Fuel consumption for carrying excess mass increases significantly when working at higher speeds (Battiato \& Diserens, 2013; Moitzi et al., 2013; Taghavifar \& Mardani, 2013). Analysis of research materials shows that optimal tractor slip in soil should be in the range of 8-12\% (Battiato \& Diserens, 2013; Keller, 2005; Moitzi et al., 2013).

The wheel slip is a critical parameter for fuel consumption and field performance. Many researchers in their works solve the problem of tractor tire slip normalization by adding ballast masses and reducing the tire pressures. However, the influence of variations in tire pressures and extra mass on tractor fuel consumption when tire slip is in the normal range (7-15\%) is considered just moderately.

Purpose of the study was to test the effect of inflation pressure in the tires and additional (ballast) mass on the slip of driving wheels, fuel consumption and work productivity for a 4 WD tractor when slip varies in the range from 7 to 15 percent and the tractor is engaged in tillage operations.

\section{Materials and Methods}

\subsection{Equipment, Site and Layout}

To test effect of tractor driving wheels slip, fuel consumption and productivity on inflation pressure in the tires and ballast mass, a tractor FORD 8340 SLE and four bodies reversible plough KONGSKILDE VARIANT VPS (Kongskilde) was composed. Specifications of the tractor used for the test are listed in Table 1, and specifications of the plough are listed in Table 2. 
Table 1. Tractor (Ford 8340 SLE) specifications

\begin{tabular}{ll}
\hline Engine: & Ford 7.5L 6-cyl diesel \\
\hline Engine model & 6 cylinder, liquid-cooled, in-line, turbocharged \\
Engine type & $82.3 \mathrm{~kW}$ at $2200 \mathrm{rpm}$ \\
PTO power (rated engine speed): & \\
\hline Transmission \& Chassis: & $4 \mathrm{WD}$ \\
\hline Drive type & Electro Shift/Pulse Command \\
Transmission type & four-speed power shift, 16 forward and reverse \\
& wet disc \\
Clutch & inboard planetary \\
Final drives: & electro-hydraulic \\
Differential lock: & $440 / 65 \mathrm{R} 24$ \\
Front tires & $18.4 \mathrm{R} 38$ \\
Rear tires & $4936 \mathrm{~kg}$ \\
\hline Tractor weight (operating) & $2.61 \mathrm{~m}$ \\
Wheelbase & closed center pressure flow compensating (pressure: 200 bar) \\
\hline Hydraulics & \\
\hline
\end{tabular}

Table 2. Plough specifications

\begin{tabular}{ll}
\hline Plough model & KONGSKILDE VARIANT VP-S \\
\hline Type & Heavy duty 4 furrow version \\
Working width of furrow & $0.3-0.52 \mathrm{~m}$ \\
Type of beam & Auto-reset \\
Weight & $1850 \mathrm{~kg}$ \\
\hline
\end{tabular}

The tractor was equipped with a data recorder - accumulator SKRT-21 Lite (TECHNOTON) with electronic clock and the software SKRT-MANAGER. Tractor sensors were used to measure engine speed, ground speed and conditional drawbar pull force. The sensors were connected in parallel to the installed instrument system SKRT. Fuel consumption (1 or $1 \mathrm{~h}^{-1}$ ) was measured by AIC-4004 VERITAS (AIC SYSTEMS AG) fuel flow meter. Calibration of all devices was performed according to standard procedures (Barzdžiukas, Augutis, \& Žilinskas, 2012; Bručas, Šiaudinyte, Rybokas, \& Grattan, 2014; Naranjo, Sandu, Taheri, \& Taheri, 2014). Error did not exceed $\pm 2 \%$. Detailed specifications of measurement devices are presented in Table 3.

Engine speed, fuel consumption, actual speed of the tractor, conditional draft indicator and time were measured during the test. Average values of measured parameters (in $15 \mathrm{~s}$ intervals) were recorded as a time function and stored in data storage. Data from data storage were then transferred in a digital form to the computer, into Microsoft Excel program (Figure 1).

Figure 1 shows how the Microsoft Excel program window displays the recorded data: Column "A" shows the recording time, columns "B" and "C" show draft (from sensors on the right and left arms respectively), column "D" - actual speed, column "E" - travelled distance during the period, column "F" - fuel consumption during the period, column "G" - hourly fuel consumption, and column " $\mathrm{H}$ " - engine speed readings. Lines 560-573 show tilling process parameters for one direction of travel. Lines 574-578 are for turning at headlands. Line 579 accounts for starting a new test. This test was carried out for the unit traveling the other direction in the field. In such a way data were continuously recorded during the total test period. The results for each test were calculated for 3 minutes of traveled distance, i.e., each test consisted of 12 intervals, each 15 seconds long. In Figure 1 we can see data of one of the test, corresponding to recorded lines 561-572. Transitional test intervals recorded in lines 560 and 573 were ignored. 
Table 3. Specifications of measurement devices

\begin{tabular}{|c|c|c|c|}
\hline Instrumentation & Measurements & Range & Accuracy \\
\hline \multirow{3}{*}{$\begin{array}{l}\text { PTO dynamometer, AW Type } 400 \text {, } \\
\text { (Perfect Power Control) }\end{array}$} & Speed & $0-1500 \mathrm{rpm}$ & $\pm 0.1 \%$ \\
\hline & Torque & $0-2850 \mathrm{Nm}$ & $\pm 0.1 \%$ \\
\hline & Power & 0-298 kW@1000 rpm & $\pm 0.2 \%$ \\
\hline $\begin{array}{l}\text { Axis scales, WPD-2, } \\
\text { EUROPE) }\end{array}$ & Mass & $5-15000 \mathrm{~kg}$ & $\pm 0.1 \% / 1,0 \mathrm{~kg}$ \\
\hline Fuel flow meter, AIC-4004 & Fuel consumption & $2.0-801 \mathrm{~h}^{-1}$ & $\pm 1 \%$ \\
\hline VERITAS, (AIC SYSTEMS AG) & & $1.0-2.01 \mathrm{~h}^{-1}$ & $+1 /-2 \%$ \\
\hline \multirow{4}{*}{$\begin{array}{l}\text { Data recorder, SKRT-21 Lite, } \\
(\text { TECHNOTON) }\end{array}$} & Software & SKRT-MANAGER & \\
\hline & Information channels & 8 & \\
\hline & Period limits & $5-180 \mathrm{~s}$ & \\
\hline & Memory capacity of each channel & $750 \mathrm{~h}$ & \\
\hline $\begin{array}{l}\text { Penetrometer, PENETROLOGGER, } \\
\text { (PENETROLOGGER) }\end{array}$ & Penetration force & $0-100 \mathrm{~N}$ & $\pm 1 \%$ \\
\hline $\begin{array}{l}\text { Moisture sensor ML2x-UM-1.21, } \\
\text { (Equitensiometers) }\end{array}$ & Soil moisture & $\mathrm{m}^{3} \mathrm{~m}^{-3}$ or $\%$ vol. & $\pm 0.5 \mathrm{~m}^{3} \mathrm{~m}^{-3}$ \\
\hline
\end{tabular}

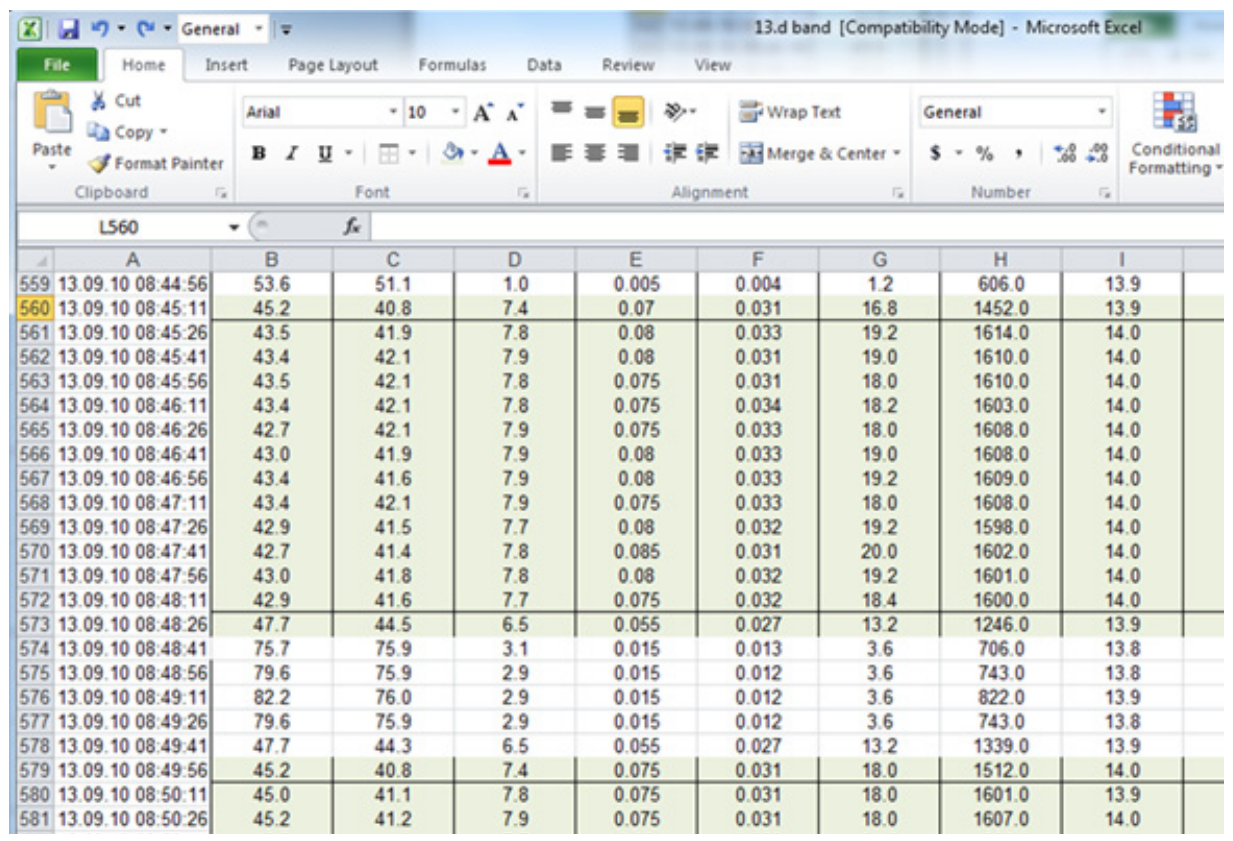

Figure 1. Information from data recorder SKRT-21 Lite transferred into Microsoft Excel program (sample)

For the test, a level, nearly smooth-texture, loamy wheat-stubble field (after wheat harvesting) strip of $380 \pm 10$ $\mathrm{m}$ length was selected. Soil moisture at a depth of $10 \mathrm{~cm}$ was $17.6 \pm 1.1 \%$, soil hardness $1.14 \pm 0.09 \mathrm{MPa}$, ambient temperature $19 \pm 2{ }^{\circ} \mathrm{C}$. The plough was set for $1.75 \mathrm{~m}$ working width and $0.20 \mathrm{~m}$ working depth. For processing of the results, a value of plough resistance to traction was accepted that prevailed during the tests. Only tests in which the traction force deviations from the prevailing (average) values did not exceed 5\% were used in the results. Slip of tractor driving wheels during all tests was $<15 \%$. Tests were carried out with front driving axle of the tractor activated, driving differentials locked and the gear $3 \mathrm{H}$ engaged, while engine speed was $1620 \pm 10 \mathrm{rpm}$. Tests were carried out by driving in one direction and then turning and driving in the opposite direction and the mean value was calculated from the obtained results. Tests were repeated 3 times. Tests were performed with $520,360,200$, and $0 \mathrm{~kg}$ ballast mass in front of the tractor. The distribution of overall 
mass of tractor on the front and rear wheels, are presented in Table 4. Tests were carried out by making all combinations of selected ballast mass of 520,360, 200 and $0 \mathrm{~kg}$ and inflation pressures in tractor tires of 240 , 190, 150 and $100 \mathrm{kPa}$ (16 combinations). Tractor tires: rear - ALLIANCE 18.4 R 38, 152 A8 ***, front ALLIANCE 440/65 R 24, 149 A8. Wear of rear tires $-4.1 \%$, front tires $-4.5 \%$.

Table 4. Distributions of the overall tractor mass on front and rear axles

\begin{tabular}{lll}
\hline Ballast mass in front of the tractor, $\mathrm{kg}$ & On the front axles, $\mathrm{kg}$ & On the rear axles, $\mathrm{kg}$ \\
\hline 0 & 1920 & 3016 \\
200 & 2180 & 2956 \\
360 & 2389 & 2907 \\
520 & 2597 & 2859 \\
\hline
\end{tabular}

\subsection{Calculations}

The wheel slip $(s)$ relates to the actual forward velocity $\left(v_{a}\right)$ of the center of wheel and the angular velocity $(\omega)$ of the wheel as follows (Battiato \& Diserens, 2013; Maclaurin, 2014; Moitzi et al., 2013; Senatore \& Sandu, 2011):

Where $R_{r}$ is the rolling radius of the wheel.

$$
s=\frac{\omega R_{r}-v_{a}}{\omega R_{r}}=1-\frac{v_{a}}{\omega R_{r}}
$$

Percent of slip of tractor was calculated according to the following equation:

$$
s=\left(1-\frac{v_{a} i_{t r}}{\omega_{e} R_{r d}}\right) 100, \%
$$

Where $v_{a}$ is the actual speed of the tractor, $\omega_{e}$ is the angular velocity of the engine shaft, $i_{t r}$ is the ratio of tractor transmission, and $R_{r d}$ is the rolling radius of driving wheels of the tractor.

The tire rolling radius $R_{r d}$ was determined according to the standard S296.2 of American Society of Agricultural Engineers (ASAE) as the distance travelled per revolution of the wheel divided by $2 \pi$, when operating at the specified zero conditions. Such conditions are assumed to be when the tractor is driving on a smooth road, and drawbar load is equal to zero (American Society of Agricultural Engineers 1983). Zoz and Grisso (2003) showed that the difference in measured rolling radiuses, when tractor is driving on a hard road compared to a test surface, is small under normal agricultural soil conditions (untilled soil), and thus has little impact on the final results. In our test the values of tractor driving wheel rolling radiuses (for each case of applied ballast mass and inflation pressure in the tires) were determined experimentally, i.e. by measuring the distance which driving wheels traveled per 10 revolutions. Tractor was not loaded by pulling force during the tests. The plough was set so that it would not till the $\operatorname{soil}\left(h_{p}=0 \mathrm{~m}\right)$.

Rolling radius of tractor driving wheels was calculated according to the following equation:

$$
R_{r d}=\frac{p_{z}}{2 \pi z}, \mathrm{~m}
$$

Where $z$ is the count of driving wheels' revolutions, $p_{z}$ is the distance traveled per count $z$ of driving wheels' revolutions, $\pi$ is the mathematical constant $(\pi=3.14)$.

Fuel consumption per hectare $B_{h a}$ was calculated according to the following equation:

$$
B_{h a}=\frac{B_{h}}{0.36 v_{a} H}, 1 \mathrm{ha}^{-1}
$$

Where $B_{h}$ is hourly fuel consumption, $H$ is working width of the unit.

\section{Results and Discussion}

The present study was focused on the tire pressure and extra weight variation effect on fuel consumption at normal tractor wheels slippage (7-15\%) during tillage operation. Figures 2, 3, 4 and 5 show tractor performance indicators' (such as ground speed, slip of driving wheels and fuel consumption) dependences on ballast mass at different inflation pressures in the tires. Figure 2 illustrates that when ballast mass was increased and inflation pressure in the tires was reduced, ground speed of tractor increased. 


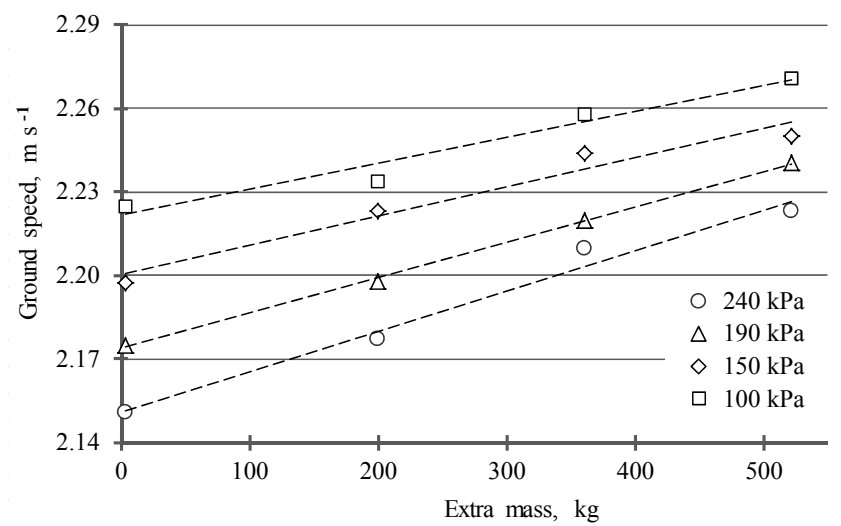

Figure 2. Ground speed dependences on the extra mass at different tire inflation pressures

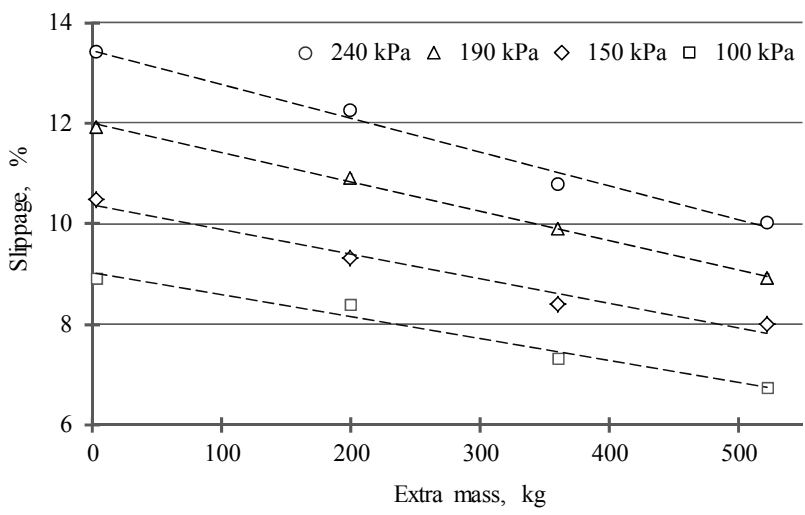

Figure 3. Driving wheels slippage dependences on the extra mass at different tire inflation pressures

Figure 3 illustrates that when ballast mass was increased and inflation pressure in the tires was reduced, slip of driving wheels decreased. When tilling work was performed with the front driving axle activated, increasing ballast mass in front of the tractor from 0 to $520 \mathrm{~kg}$ reduced slip on average by nearly $2.8 \%$. When inflation pressure in the tires was $240 \mathrm{kPa}$, increasing ballast mass from 0 to $520 \mathrm{~kg}$ reduced slip from $13.5 \%$ to $10.2 \%$. When inflation pressure in the tires was $190 \mathrm{kPa}$, slip decreased from $11.7 \%$ to $9.1 \%$. When inflation pressure in the tires was $150 \mathrm{kPa}$, slip decreased from $10.3 \%$ to $7.8 \%$. When inflation pressure in the tires was $100 \mathrm{kPa}$, slip decreased from $9.0 \%$ to $6.7 \%$. After reducing inflation pressure in the tires from $240 \mathrm{kPa}$ to $100 \mathrm{kPa}$, slip decreased on average by $3.8 \%$. From the results presented in Figure 3 we can see that tractor slip varied in the range from 6.5 to $13.5 \%$ during all the tests. This corresponds to the tractor slip that is recommended for tillage works in a number of sources (Battiato \& Diserens, 2013; Battiato, Diserens, Laloui, \& Sartori, 2013; Moitzi et al., 2013; Srinivasa Rao et al., 2012; Šmerda \& Čupera, 2010). In loam stubble of average moisture and hardness, such slip corresponds to adequate grip of driving wheels with the soil (Battiato \& Diserens, 2013; Janulevičius \& Giedra, 2008; Maclaurin, 2014; Zoz \& Grisso, 2003). 


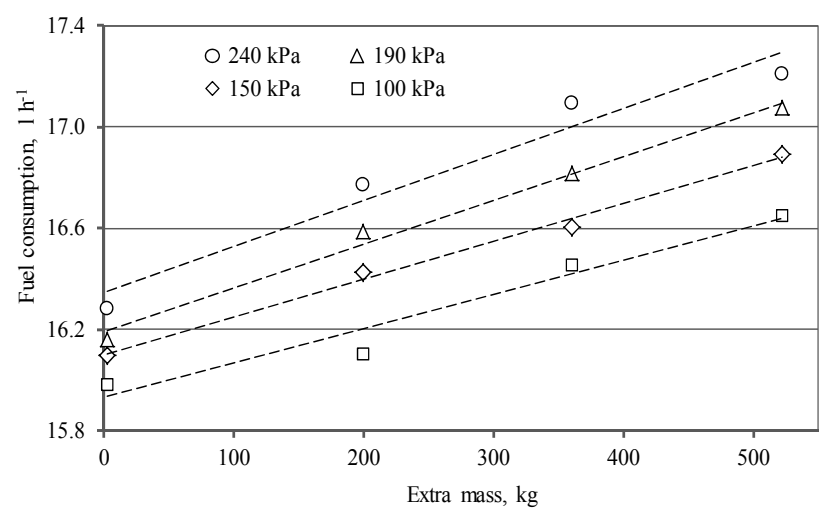

Figure 4. Tractor hourly fuel consumption dependences on the extra mass at different tire inflation pressures

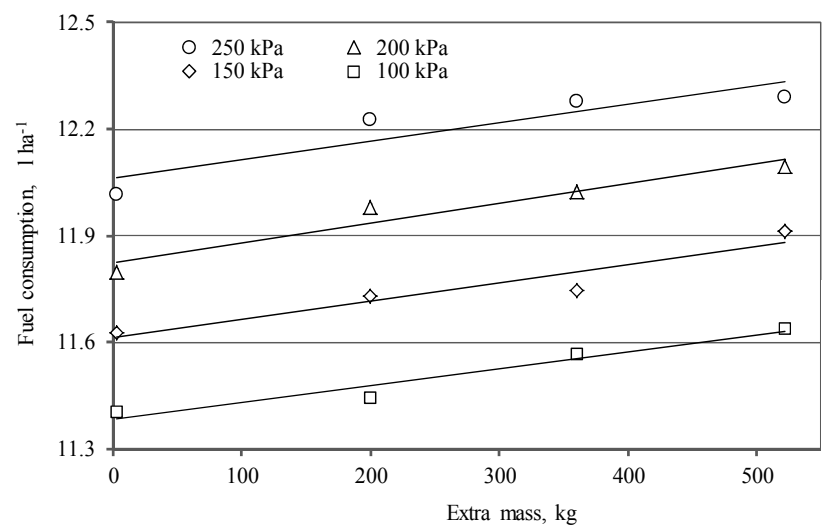

Figure 5. Tractor fuel consumption per hectare dependences on the extra mass at different tire inflation pressures

Figures 4 and 5 shows that when the ballast mass was increased, tractor fuel consumption also increased. When inflation pressure in the tires was $240 \mathrm{kPa}$, after increasing the ballast mass from 0 to $520 \mathrm{~kg}$, hourly fuel consumption (Figures 4) increased from $16.31 \mathrm{~h}^{-1}$ to $17.25 \mathrm{lh}^{-1}$, and fuel consumption per hectare (Figures 5) increased from $12.01 \mathrm{ha}^{-1}$ to $12.3 \mathrm{l} \mathrm{ha}^{-1}$. When inflation pressure in the tires was $190 \mathrm{kPa}$, hourly fuel consumption increased from $16.21 \mathrm{~h}^{-1}$ to $17.1 \mathrm{l} \mathrm{h}^{-1}$, and fuel consumption per hectare increased from $11.81 \mathrm{ha}^{-1}$ to $12.1 \mathrm{~h} \mathrm{ha}^{-1}$. When inflation pressure in the tires was $150 \mathrm{kPa}$, hourly fuel consumption increased from $16.1 \mathrm{l} \mathrm{h}^{-1}$ to $16.91 \mathrm{~h}^{-1}$, and fuel consumption per hectare increased from $11.61 \mathrm{ha}^{-1}$ to $11.91 \mathrm{ha}^{-1}$. When inflation pressure in the tires was $100 \mathrm{kPa}$, hourly fuel consumption increased from $16.0 \mathrm{~kg} \mathrm{~h}^{-1}$ to $16.7 \mathrm{~kg} \mathrm{~h}^{-1}$, and fuel consumption per hectare increased from $11.41 \mathrm{ha}^{-1}$ to $11.61 \mathrm{ha}^{-1}$. When loam stubble was tilled with tractor front driving axle activated, after increasing the front ballast mass from 0 to $520 \mathrm{~kg}$, hourly fuel consumption increased on average by $0.8 \mathrm{l} \mathrm{h}^{-1}$, and fuel consumption per hectare increased by $0.31 \mathrm{ha}^{-1}$. These results do not include fuel consumption per hectare at the headlands. When tire inflation pressure was lowered from $240 \mathrm{kPa}$ to $100 \mathrm{kPa}$, hourly fuel consumption fell on average by $0.51 \mathrm{~h}^{-1}$, and fuel consumption per hectare - by $0.71 \mathrm{ha}^{-1}$. For the sufficient grip conditions, tractor ballast reduces driving wheels slip, but increases fuel consumption. When tire inflation pressure is reduced, the driving wheels slip, and tractor fuel consumption is reduced. Tractor work productivity, hourly fuel consumption and fuel consumption per hectare, dependence on the driving wheels slip, tires inflation pressure and the extra mass (ballast weights) is presented in Figures 6, 7 and 8, respectively. 


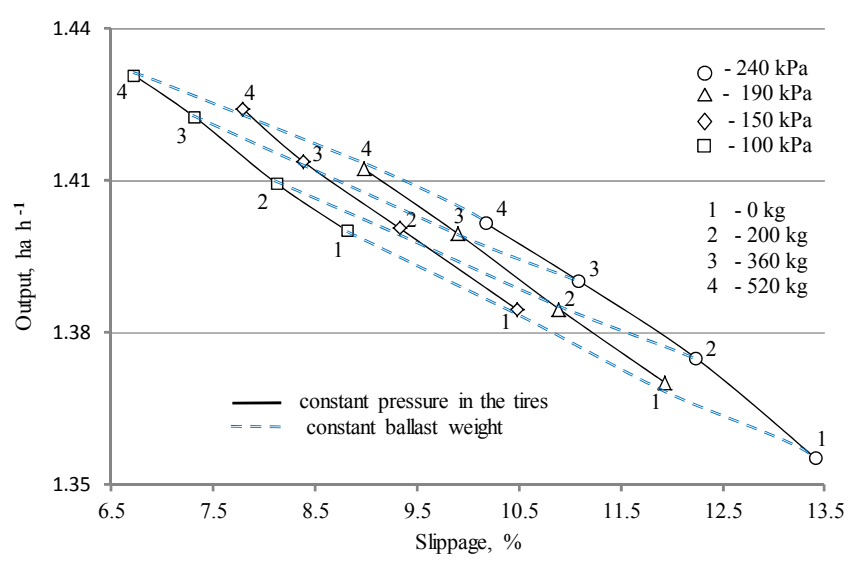

Figure 6. Work productivity dependences on driving wheel slippage, tire inflation pressures and extra mass (ballast weights)

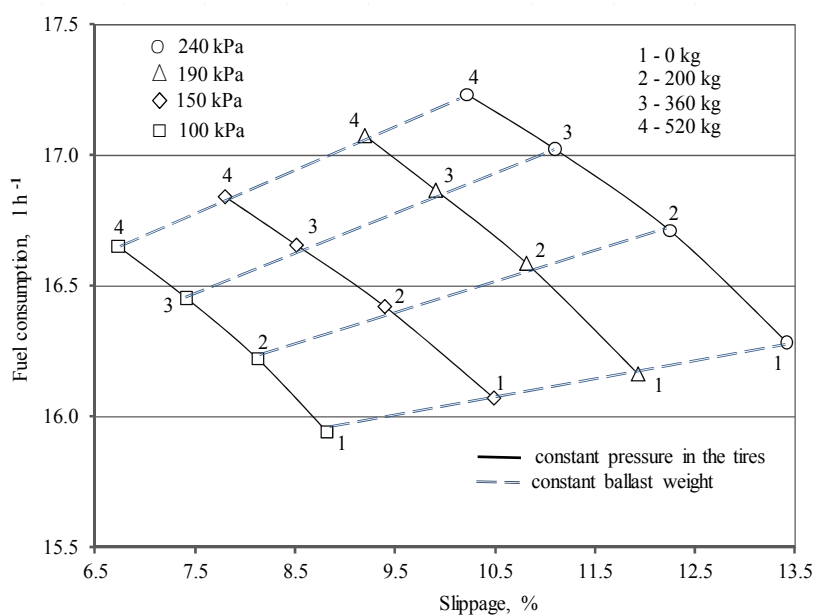

Figure 7. Hourly fuel consumption dependences on driving wheel slippage, tire inflation pressures and extra mass (ballast weights)

Figures 6,7 and 8 illustrates that when extra mass (ballast weights) was added and inflation pressure in the tires was reduced, slip of driving wheels decreased. When extra mass (ballast weights) is added, slip of driving wheels decreases, and work productivity increases together with increased fuel consumption. Keeping tire inflation pressure constant and increasing the ballast mass from 0 to $520 \mathrm{~kg}$, slip of driving wheels decreased on average $2.3 \%$, work productivity increased by approximately $0.04 \mathrm{ha} \mathrm{h}^{-1}$, hourly fuel consumption increased by nearly $0.9 \mathrm{l} \mathrm{h}^{-1}$, and fuel consumption per hectare increased by nearly $0.31 \mathrm{ha}^{-1}$. When tire inflation pressure is reduced, driving wheels slip as well as fuel consumption decreases, while productivity increases. Keeping tractor ballast mass constant and reducing the tire inflation pressure from $240 \mathrm{kPa}$ to $100 \mathrm{kPa}$, driving wheel slip decreased on average $4.2 \%$, hourly fuel consumption also decreased by approximately $0.51 \mathrm{~h}^{-1}$, fuel consumption per hectare decreased by approximately $0.31 \mathrm{ha}^{-1}$, and work productivity increased by about $0.035 \mathrm{ha} \mathrm{h}^{-1}$. 


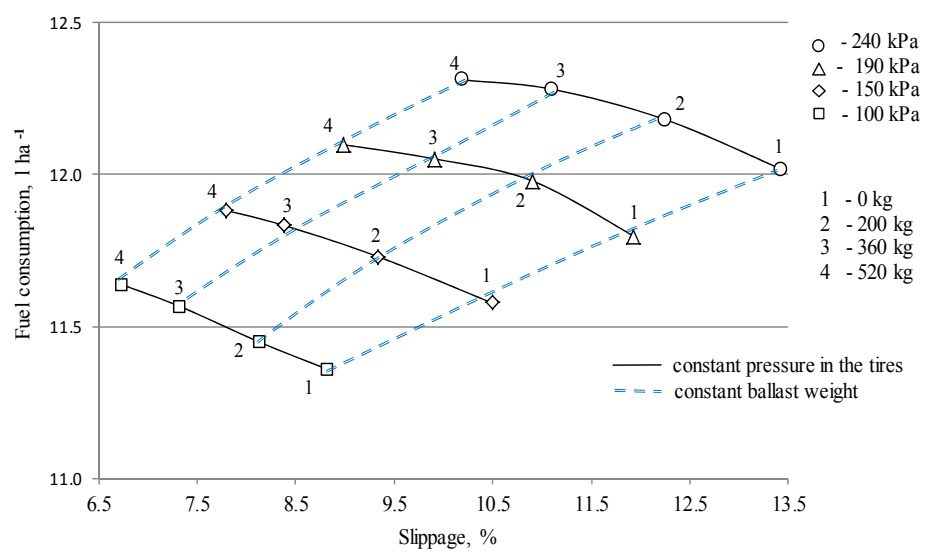

Figure 8. Fuel consumption per hectare dependences on driving wheel slippage, tire inflation pressures and extra mass (ballast weights)

Figure 6 shows that the largest slip of driving wheels (13.5\%) and the lowest work productivity $\left(1.36 \mathrm{ha} \mathrm{h}^{-1}\right)$ occurred when working without ballast weights and when tire inflation pressure was $240 \mathrm{kPa}$ (maximum). Minimum slip of driving wheels $(6.6 \%)$ and the highest productivity $\left(1.43 \mathrm{ha} \mathrm{h}^{-1}\right)$ occurred when tire inflation pressure was $100 \mathrm{kPa}$ (minimum) and ballast weight mounted in front of the tractor was $520 \mathrm{~kg}$ (maximum). Figures 7 and 8 show that the lowest hourly fuel consumption $\left(16.0 \mathrm{l} \mathrm{h}^{-1}\right)$ and the lowest fuel consumption per hectare $\left(11.41 \mathrm{ha}^{-1}\right)$ occurred when the tractor was working without ballast weights and tire inflation pressure was $100 \mathrm{kPa}$ (minimum). When the work was being done in the mode of the lowest fuel consumption, driving wheels slip $8.8 \%$, and the work productivity was $1.39 \mathrm{ha} \mathrm{h}^{-1}$.

The highest hourly fuel consumption $\left(17.21 \mathrm{~h}^{-1}\right)$ and the highest fuel consumption per hectare $\left(12.31 \mathrm{ha}^{-1}\right)$ occurred when the tractor was working with the biggest ballast weight $(520 \mathrm{~kg})$ and tire inflation pressure was $240 \mathrm{kPa}$ (maximum). When working in a mode of maximum fuel consumption, the slip of driving wheels was not the greatest and work productivity was not minimal.

The dependencies of fuel consumption and productivity on the driving wheel slip, tire inflation pressure and extra mass (ballast weight) reveal preparation of the tractor for implementation of the desired operating parameters found in this study. The results of this study may provide helpful insights into a reasonable choice of tractor configuration as well as effective control of driving wheel slip, with a view to optimizing tractor performance parameters, thereby saving time and reducing the costs of tillage.

\section{Conclusions}

The aim of present study was to analyze the effect of variations in tire inflation pressures and extra mass on the fuel consumption and productivity of a 4 WD tractor when tire slip varied in the range from 7 to 15 percent (normal slip in the soil).

When normal slip occurs, reduced the inflation pressure decreases the driving wheel slip and fuel consumption, and increases work productivity. Added weight of the tractor decreases the driving wheel slip and increases work productivity, but also increases fuel consumption.

When tilling wheat stubble where soil moisture content in $10 \mathrm{~cm}$ depth was $17.6 \pm 1.1 \%$ and hardness was $1.14 \pm$ $0.09 \mathrm{MPa}$, reducing inflation pressure from $240 \mathrm{kPa}$ to $100 \mathrm{kPa}$ resulted in driving wheel slippage to decrease on average $4.2 \%$, hourly fuel consumption also dropped by approximately $0.51 \mathrm{~h} \mathrm{~h}^{-1}$ work productivity increased by about $0.035 \mathrm{ha} \mathrm{h}^{-1}$, and fuel consumption per hectare decreased by approximately $0.51 \mathrm{ha}^{-1}$. Adding weight from 0 to $520 \mathrm{~kg}$ caused slip of driving wheels to decrease by average $2.3 \%$, while hourly fuel consumption increased by nearly $0.9 \mathrm{l} \mathrm{h}^{-1}$, work productivity increased by approximately $0.04 \mathrm{ha} \mathrm{h}^{-1}$, and fuel consumption per hectare increased by nearly $0.31 \mathrm{ha}^{-1}$.

In conclusion, the ballast weight and tire pressure reductions during normal slippage of the tractor wheels bring a positive effect on fuel consumption, maintaining the same slippage.

The results of this study may provide helpful insights into a reasonable choice of tractor configuration as well as effective control of driving wheel slip, with a view to optimizing tractor performance parameters, thereby saving time and reducing the costs of tillage. 


\section{Acknowledgements}

The authors highly appreciate the comments and suggestions of the anonymous reviewers, which significantly contributed to improve the manuscript.

\section{References}

American Society of Agricultural Engineers. (1983). ASAE Standard S296.2 - Uniform terminology for traction of Agricultural Tractors, Self-Propelled Implements, and other Traction and Transport Devices. Agricultural engineers yearbook of standards. St. Joseph, Mich.: ASAE.

Backman, J., Oksanen, T., \& Visala, A. (2013). Applicability of the ISO 11783 network in a distributed combined guidance system for agricultural machines. Biosystems Engineering, 114, 306-317. http://dx.doi.org/10.1016/j.biosystemseng.2012.12.017

Barzdžiukas, J., Augutis, S. V., \& Žilinskas, R. P. (2012). The precise measurement of car velocity. Transport, 27(2), 138-142. http://dx.doi.org/10.3846/16484142.2012.690346

Battiato, A., \& Diserens, E. (2013). Influence of Tyre Inflation Pressure and Wheel Load on the Traction Performance of a 65 kW MFWD Tractor on a Cohesive Soil. Journal of Agricultural Science, 5(8), 197-215. http://dx.doi.org/10.5539/jas.v5n8p197

Battiato, A., Diserens, E., Laloui, L., \& Sartori, L. (2013). A Mechanistic Approach to Topsoil Damage due to Slip of Tractor Tyres. Journal of Agricultural Science and Applications, 2(3), 160-168. http://dx.doi.org/10.14511/jasa.2013.020305

Bručas, D., Šiaudinytè, L., Rybokas, M., \& Grattan, K. (2014). Theoretical aspects of the calibration of geodetic angle measurement instrumentation. $\quad$ Mechanika, 20(1), 113-117. http://dx.doi.org/10.5755/j01.mech.20.1.6590

Dagiliūtè, R., \& Juknys, R. (2012). Eco-efficiency: trends, goals and their implementation in Lithuania. Journal of Environmental Engineering and Landscape Management, 20(4), $265-272$. http://dx.doi.org/10.3846/16486897. 2012. 661072

Grisso, R., Pitman, R., Perumpral, J. V., Vaughan, D., Roberson, G. T,. \& Hoy, R. M. (2011). "Gear Up and Throttle Down" to Save Fuel. VCE Publication, 442-450. Retrieved from http://pubs.ext.vt.edu/442/442-450/442-450_pdf.pdf

Hashemi, A., Ahmad, D., Othman, J., \& Sulaiman, S. (2012). Development and Testing of a New Tillage Apparatus. Journal of Agricultural Science, 4(7), 103-110. http://dx.doi.org/10.5539/jas.v4n7p103

Janulevičius, A., \& Giedra, K. (2008). Tractor ballasting in field work. Mechanika, 5(73), 27-34. Retrieved from http://zurnalas.mechanika.ktu.lt/files/Janulevicius573.pdf

Janulevičius, A., Juostas, A., \& Pupinis, G. (2013). Tractor's engine performance and emission characteristics in the process of ploughing. Energy Conversion and Management, 75, 498-508. http://dx.doi.org/10.1016/j.enconman.2013.06.052

Juostas, A., \& Janulevičius, A. (2014). Tractor's engine efficiency and exhaust emissions' research in drilling work. Journal of Environmental Engineering and Landscape Management, 22(02), 141-150. http://dx.doi.org/10.3846/16486897.2013.852556

Keller, T. (2005). A model for the prediction of the contact area and the distribution of vertical stress below agricultural tyres from readily available tyre parameters. Biosystems Engineering, 92(1), 85-96. http://dx.doi.org/10.1016/j.biosystemseng.2005.05.012

Khambalkar, V., Pohare, J., Katkhede, S., Bunde, D., \& Dahatonde, S. (2010). Energy and Economic Evaluation of Farm Operations in Crop Production. Journal of Agricultural Science, 2(4), 191-200. http://dx.doi.org/10.5539/jas.v2n4p191

Kheiralla, A. F., Azmi, Y., Zohadie, M., \& Ishak, W. (2004) Modelling of power and energy requirements for tillage implements operating in Serdang sandy clay loam, Malaysia. Soil \& Tillage Research, 78, 21-34. http://dx. doi:10.1016/j.still.2003.12.011

Lacour, S., Burgun, C., Perilhon, C., Descombes, G., \& Doyen, V. (2014). A model to assess tractor operational efficiency from bench test data. Journal of Terramechanics, 54, 1-18. http://dx.doi.org/10.1016/j.jterra.2014.04.001

Lyasko, M. I. (2010). How to calculate the effect of soil conditions on tractive performance. Journal of 
Terramechanics, 47, 423-445. http://dx.doi.org/10.1016/j.jterra.2010.04.003

Maclaurin, B. (2014). Using a modified version of the Magic Formula to describe the traction/slip relationships of tyres in soft cohesive soils. Journal of Terramechanics, 52, 1-7. http://dx.doi.org/10.1016/j.jterra.2013.11.005

Macor, A., \& Rossetti, A. (2013). Fuel consumption reduction in urban buses by using power split transmissions. Energy Conversion and Management, 71, 159-171. http://dx.doi.org/10.1016/j.enconman.2013.03.019

Magalhães, A. C., Souza, J. M, Santana, M. A., \& Sabbag, O. J. (2013). Analysis of the Mechanization Index of Wheel Tractors in Rural Farm Holdings. Journal of Agricultural Science, 5(44), 127-138. http://dx.doi.org/10.5539/jas.v5n11p127

Moitzi, G., Haas, M., Wagentristl, H., Boxberger, J., \& Gronauer, A. (2013). Energy consumption in cultivating and ploughing with traction improvement system and consideration of the rear furrow wheel-load in ploughing. Soil \& Tillage Research, 134, 56-60. http://dx.doi.org/10.1016/j.still.2013.07.006

Molari, G., Bellentani, L., Guarnieri, A, Walker, M., \& Sedoni, E. (2012). Performance of an agricultural tractor fitted with rubber tracks. Biosystems engineering, 111, 57-63. http://dx.doi.org/10.1016/j.biosystemseng.2011.10.008

Naranjo, S. D., Sandu, C., Taheri, S., \& Taheri, S. (2014). Experimental testing of an off-road instrumented tire on soft soil. Journal of Terramechanics, 56, 119-137. http://dx.doi.org/10.1016/j.jterra.2014.09.003

Patterson, M. S., Gray, J. P., Bortolin, G., \& Vantsevich, V. V. (2013). Fusion of driving and braking tire operational modes and analysis of traction dynamics and energy efficiency of a 4 x 4 loader. Journal of Terramechanics, 50, 133-152. http://dx.doi.org/10.1016/j.jterra.2013.01.003

Peca, J. O., Serrano, J. M., Pinheiro, A., Carvalho, M., Nunes, M., Ribeiro, L., \& Santos, F. (2010). Speed advice for power efficient drawbar work. Journal of Terramechanics, 47, 55-61. http://dx.doi.org/10.1016/j.jterra.2009.07.003

Pranav, P. K., \& Pandey, K. P. (2008). Computer simulation of ballast management for agricultural tractors. Journal of Terramechanics, 45, 193-200. http://dx.doi.org/10.1016/j.jterra.2008.12.002

Saengprachatanarug, K., Ueno, M., Taira, E., \& Okayasu, T. (2013). Modeling of soil displacement and soil strain distribution under a traveling wheel. Journal of Terramechanics, 50, 5-16. http://dx.doi.org/10.1016/j.jterra.2012.06.001

Senatore, C., \& Sandu, C. (2011). Torque distribution influence on tractive efficiency and mobility of off-road wheeled vehicles. Journal of Terramechanics, 48, 372-383. http://dx.doi.org/10.1016/j.jterra.2011.06.008

Srinivasa Rao, S., Ramji, K., \& Naidu, M. K. (2012). Analytical approach for the prediction of steady state tyre forces and moments under different normal pressure distributions. Journal of Terramechanics, 49, 281-289. http://dx.doi.org/10.1016/j.jterra.2012.10.002

Stoilov, S., \& Kostadinov, G. D. (2009). Effect of weight distribution on the slip efficiency of a four-wheel-drive skidder. Biosystems engineering, 104, 486-492. http://dx.doi.org/10.1016/j.biosystemseng.2009.08.011

Szendrő, G., \& Török, Á. (2014). Theoretical investigation of environmental development pathways in the road transport sector in the European Region. Transport, 29(1), 12-17. http://dx.doi.org/10.3846/16484142.2014.893538

Šmerda, T., \& Čupera, J. (2010). Tire inflation and its influence on drawbar characteristics and performance Energetic indicators of a tractor set. Journal of Terramechanics, 47, 395-400. http://dx.doi.org/10.1016/j.jterra.2010.02.005

Taghavifar, H., \& Mardani, A. (2014). On the modeling of energy indices of agricultural tractor driving wheels applying adaptive neuro-fuzzy inference system. Journal of Terramechanics, 56, 37-47. http://dx.doi.org/10.1016/j.jterra.2014.08.002

Taghavifar, H., \& Mardani, A. (2013). Investigating the effect of velocity, inflation pressure, and vertical load on rolling resistance of a radial ply tire. Journal of Terramechanics, 50, 99-106. http://dx.doi.org/10.1016/j.jterra.2013.01.005

Vantsevich, V. V. (2008). Power losses and energy efficiency of multi-wheel driver vehicles: A method for evaluation. Journal of Terramechanics, 45, 89-101. http://dx.doi.org/10.1016/j.jterra.2008.08.001

Way, T. R, \& Kishimoto, T. (2004). Interface pressures of a tractor drive tyre on structured and loose soils. 
Biosystems Engineering, 87(3), 375-386. http://dx.doi.org/10.1016/j.biosystemseng.2003.12.001

Wong, J. Y. (2010). Terramechanics and off-road vehicle engineering (2nd ed.). Elsevier.

Xia, K. (2011). Finite element modeling of tire/terrain interaction: Application to predicting soil compaction and tire mobility. Journal of Terramechanics, 48, 113-123. http://dx.doi.org/10.1016/j.jterra.2010.05.001

Zoz, F. M., \& Grisso, R. D. (2003). Traction and tractor performance. ASAE distinguished lecture series (Tractor design No. 27). ASAE publication No. 913C0403. St. Joseph, Mich.: ASAE. Retrieved from http://bsesrv214.bse.vt.edu/Dist_Lecture_27/Resources/Traction_Tractor_Performance.PDF

\section{Appendix}

Appendix 1

4WD: four-wheel drive;

$B_{h a}$ : fuel consumption per hectare $\left(1 \mathrm{ha}^{-1}\right)$;

$B_{h}$ : hourly fuel consumption $\left(1 \mathrm{~h}^{-1}\right)$;

$H$ : working width of the unit $(\mathrm{m})$;

$h_{p}$ : ploughing depth (m);

$s$ : wheel slip coefficients;

$\pi$ : mathematical constant $(\pi \approx 3.14)$;

$z$ : revolutions of the wheel;

$i_{t r}$ : gear-ratio of the tractor transmission;

$R_{r}$ : rolling radius of the wheel (m);

$R_{r d}$ : rolling radius of the drive wheels of tractor $(\mathrm{m})$;

$p_{z}$ : distance of wheels travel during $z$ rotations $(\mathrm{m})$;

$v_{a}$ : actual speed $\left(\mathrm{m} \mathrm{s}^{-1}\right)$;

$\omega$ : angular velocity of the wheel $\left(\mathrm{s}^{-1}\right)$;

$\omega_{e}$ : angular velocity of the engine $\left(\mathrm{s}^{-1}\right)$.

\section{Copyrights}

Copyright for this article is retained by the author(s), with first publication rights granted to the journal.

This is an open-access article distributed under the terms and conditions of the Creative Commons Attribution license (http://creativecommons.org/licenses/by/3.0/). 